\title{
An alkaline polymer electrochemical interface: a breakthrough in application of alkaline anion-exchange membranes in fuel cells
}

\author{
John R. Varcoe, ${ }^{* a}$ Robert C. T. Slade ${ }^{a}$, Eric Lam How Yee ${ }^{a}$ \\ Receipt/Acceptance Data [DO NOT ALTER/DELETE THIS TEXT] \\ ${ }_{5}$ Publication data [DO NOT ALTER/DELETE THIS TEXT] \\ DOI: 10.1039/b000000x [DO NOT ALTER/DELETE THIS TEXT]
}

\begin{abstract}
A novel alkaline polymer has been developed as an interfacial material for use in preparation of metal-cation-free alkaline membrane electrode assemblies (MEAs) for all-solid-state 10 alkaline fuel cells (AFCs) with long-term performance stability.
\end{abstract}

There is now considerable interest in the application of alkaline anion-exchange membranes (AAEMs, $\mathrm{OH}^{-}$-conducting membranes) in fuel cells. The advantages and disadvantages of this have been detailed in recent reviews, ${ }^{1}$ a summary of the benefits 15 being: (1) enhanced electrokinetics with the potential for the use of non-noble metal catalysts, such as $\mathrm{Ag}^{2}$, and higher energy density fuels compared to methanol, such as ethylene glycol; ${ }^{2}$ (2) lowered alcohol permeability; ${ }^{3}$ and (3) improved water management. ${ }^{1}$ The major inhibitor to the successful application of AAEMs in fuel cells 20 is the current lack of an alkaline analogue to the commercially available Nafion ${ }^{\circledR}$ proton-exchange polymer dispersions that are used in producing the high performance membrane electrode assemblies (MEAs) found in current state-of-the-art protonexchange- membrane fuel cells. Hence, non-ideal strategies, such 25 as adding $\mathrm{KOH}$ into the alcohol fuel supply and electrode structures or use of Nafion ${ }^{\circledR}$ dispersions, ${ }^{2-4}$ have been implemented. It is essential that no metal cations (e.g. $\left.\mathrm{K}^{+}, \mathrm{Na}^{+}\right)$are present in alkaline fuel cells in which $\mathrm{CO}_{2}$ is supplied to or generated at the electrodes, otherwise undesirable carbonate precipitation will occur, a major 30 problem with traditional aqueous $\mathrm{KOH}$ electrolyte AFCs. ${ }^{5}$

The breakthrough reported in this communication is the successful development of a cross-linked $\left(\mathrm{OH}^{-}\right.$-exchanging but water insoluble) alkaline interface polymer (Scheme 1) that allows the preparation of AAEM-MEAs ${ }^{\dagger}$ that do not contain any $\mathrm{M}^{\mathrm{n}+}$ ions: 35 the counter ions (quaternary ammonium groups) to the $\mathrm{OH}^{-}$ conduction species are bound to the polymer backbone in the same manner as the counter ions ( $\mathrm{SO}_{3}{ }^{-}$groups) are bound to the polymer backbone in commercial $\mathrm{H}^{+}$-conducting polymers (e.g. Nafion $\left.{ }^{\circledR}\right)$. This work follows on from the extensive development of state-of40 the-art conductive, chemically and thermally stable quaternaryammonium-containing AAEMs by the authors. ${ }^{6:} N, N, N^{\prime}, N^{\prime}$ tetramethylhexane-1,6-diamine was selected as the amination / cross-linking agent due to recent reports that cross-linked polymers synthesised using this diamine exhibited high stability towards ${ }_{45}$ alkali. $^{7}$ Reaction between the diamine and poly(vinylbenzyl chloride) was confirmed using Raman spectroscopy. ${ }^{\S}$

Figure 1 compares the $\mathrm{H}_{2} / \mathrm{O}_{2}$ fuel cell performance curves obtained with AAEM-MEAs both with and without the alkaline interface. It was seen that there was a substantial increase in the ${ }_{50}$ peak power density at $50^{\circ} \mathrm{C}$ (from 1.6 to $55 \mathrm{~mW} \mathrm{~cm}^{-2}$ ) on simply

${ }^{a}$ Chemistry(C4), The University of Surrey, Guildford, GU2 7XH, United Kingdom. Fax: +44 1483 686851; Tel: +44 1483 682616; E-mail: j.varcoe@surrey.ac.uk

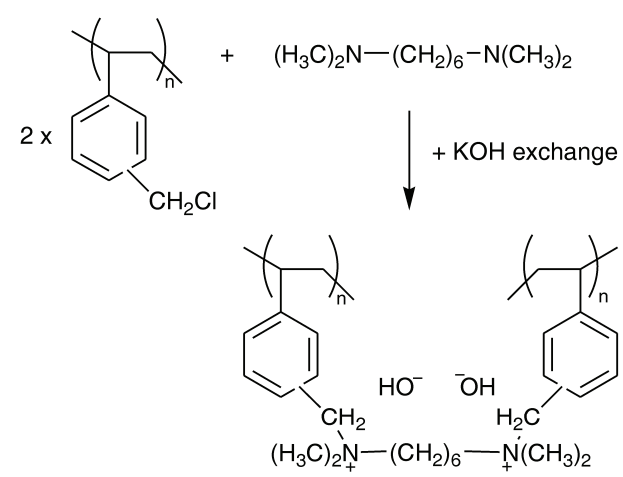

Scheme 1 Cross-linked alkaline interface polymer synthesis.

adding the interface polymer. It should be noted that the electrodes used for the MEA without interface polymer contained $4 \mathrm{mg} \mathrm{cm}^{-2}$ Pt black and not the $0.5 \mathrm{mg} \mathrm{cm}^{-2} \mathrm{Pt} / \mathrm{C}$ used for the MEA with the interface, as the performances were otherwise too poor to measure. 55 As a control experiment, an AAEM-MEA was fabricated with electrodes treated with diamine and $\mathrm{KOH}$ only i.e. without added poly(vinylbenzyl chloride); this resulted in no increase in performance. The above result compares well with the $42 \mathrm{~mW} \mathrm{~cm}^{-2}$ peak power density obtained at $25^{\circ} \mathrm{C}$ by Agel et al., ${ }^{4}$ who used a ${ }_{60} \mathrm{KOH}-$ based MEA alkaline interface with an AAEM that exhibited sufficient conductivity only with the pre-adsorption of $\mathrm{KOH}$.

The work reported above constitutes the first attempt at an all solid state AAEM-MEA and produced a performance that was

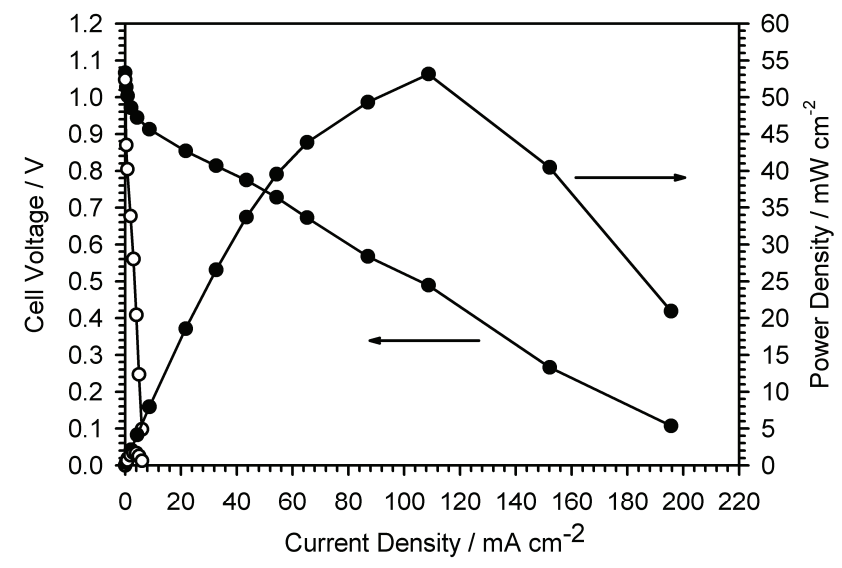

Fig. 1 Fuel cell test data obtained with AAEM-MEAs with $0.5 \mathrm{mg} \mathrm{cm}^{-2}$ $\mathrm{Pt} / \mathrm{C}(20 \% \mathrm{wt})$ electrodes coated with the alkaline interface polymer $(\bullet)$ and with $4 \mathrm{mg} \mathrm{cm}^{-2} \mathrm{Pt}$ black electrodes without the interface (O). Test conditions: $50^{\circ} \mathrm{C}, 2 \mathrm{dm}^{3} \mathrm{~min}^{-1} \mathrm{RH}=100 \% \mathrm{O}_{2}$ and $\mathrm{H}_{2}$ gas flows at the cathode and anode respectively, no added back pressures. 
within 1 order of magnitude of an MEA containing proton${ }_{65}$ exchange materials that have been optimised over decades. A peak power density of $480 \mathrm{~mW} \mathrm{~cm}$ was obtained when a traditional Nafion1 $15^{\pi}$-containing MEA (with the application of dispersed Nafion onto $4 \mathrm{mg} \mathrm{cm}^{-2}$ Pt black electrodes at the same loading as that used for the AAEM-MEA) was tested under the same 70 conditions. Internal resistance measured throughout fuel cell testing (standard current pulse) with the Nafion115-MEA $\left(0.4 \Omega \mathrm{cm}^{2}\right)$ was lower than that found with the AAEM-MEA $\left(1.5 \Omega \mathrm{cm}^{2}\right)$, which was a contributing factor towards the lower power performance of the latter. Further noteworthy points are that (1) the AAEM used, 75 (2) the level of loading of the alkaline interface polymer, and (3) the electrode fabrication methodology are all far from optimised; a study into these factors is now being undertaken, and higher performances are anticipated in the future.

An AAEM-MEA was tested in methanol $/ \mathrm{O}_{2}$ mode (direct 80 methanol fuel cell, DMFC) under the same test conditions as the $\mathrm{H}_{2} / \mathrm{O}_{2}$ test presented in Figure 1, except that the $\mathrm{H}_{2}$ anode supply was replaced with preheated aqueous methanol $\left(50^{\circ} \mathrm{C}, 2 \mathrm{~mol} \mathrm{dm}^{-3}\right.$, $10 \mathrm{~cm}^{3} \mathrm{~min}^{-1}$, no back pressure). This gave a peak power density of $0.9 \mathrm{~mW} \mathrm{~cm}^{-2}$. This compares poorly to recent results published by ${ }_{85}$ Scott et al. using a commercial AAEM (Morgane ${ }^{\circledR}$-ADP, Solvay S.A., Belgium) where peak power densities of $18 \mathrm{~mW} \mathrm{~cm}^{-2}$ were obtained; ${ }^{8}$ these performances were, however, obtained with $\mathrm{KOH}$ added to the aqueous methanol anode fuel supply. As mentioned above, this neutralises any advantage with replacing aqueous $\mathrm{KOH}$

90 electrolyte with AAEMs in AFCs; the absence of mobile metal cations eliminates problematic, potentially performance destroying, carbonate precipitation in the electrode structures. ${ }^{5}$

Figure 2 presents a $233 \mathrm{~h}$ durability test, with the same AAEMMEA, tested in methanol/air mode $\left(\mathrm{CO}_{2}\right.$ supplied to the cathode as 95 a component of air and generated at the anode from electrooxidation of methanol). The results constitute a breakthrough in AFC technology. The cell voltage stabilised to a degradation rate of $95 \pm 10 \mu \mathrm{V} \mathrm{h}^{-1}$ (with no associated increase in cell area resistance measured to be $5.9 \pm 0.2 \Omega \mathrm{cm}^{2}$ throughout the test); this represents 100 a respectable performance degradation for any type of DMFC. This performance data indicates that the interface polymer is crosslinked. After this $233 \mathrm{~h}$ test, the methanol $/ \mathrm{O}_{2}$ performance was reevaluated, and the peak power density was observed to have increased to $1.1 \mathrm{~mW} \mathrm{~cm}^{-2}$; this clearly indicates that performance 105 was recoverable. The ion-exchange capacity of the membrane after the $233 \mathrm{~h}$ test had reduced by less that $5 \%$. In contrast, the performance of a $\mathrm{KOH}$ electrolyte $\mathrm{AFC}\left(6 \mathrm{~mol} \mathrm{dm}^{-3}\right)$ degraded rapidly over the course of $70 \mathrm{~h}$ at $60^{\circ} \mathrm{C}$ and $94 \mathrm{~h}$ at $30^{\circ} \mathrm{C}$, due to carbonate precipitation at the anode, when fuelled with methanol. ${ }^{9}$

110 The above observations demonstrate that elimination of $\mathrm{M}^{\mathrm{n}+}$ cations in such systems minimises performance losses due to carbonation, thereby allowing alcohols to be used in AFCs. This is contrary to current wisdom and fully validates the innovative approach outlined in this article. Future work, as well as the MEA 115 optimisation mentioned above, will include the evaluation of Pd-, $\mathrm{Ag}$ - and Au-containing electrodes in AAEM-MEAs.

We thank the EPSRC for funding (grant GR $\backslash S 60709 \backslash 01$ ).

\section{Notes and references}

$\dagger$ Poly(vinylbenzyl chloride) (Aldrich, meta-/para- mixture) was 120 dissolved in ethyl acetate $\left(50 \mathrm{mg} \mathrm{cm}^{-3}\right)$ and sprayed to a loading of $0.97 \pm$ $0.05 \mathrm{mg} \mathrm{cm}^{-2}$ onto the catalysed side of standard commercial carbon-cloth

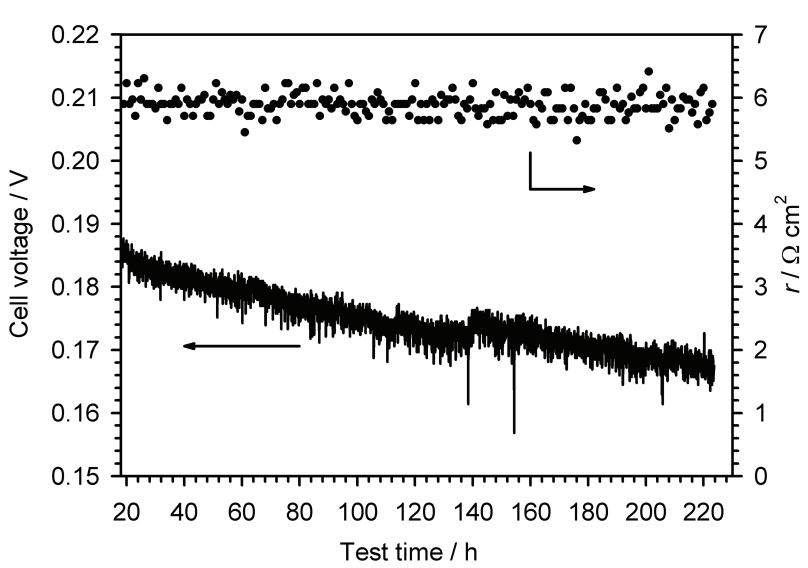

Fig. 2 Medium-term test with an AAEM-MEA ( $4 \mathrm{mg} \mathrm{cm}^{-2} \mathrm{PtRu}_{\mathrm{ox}}$ anode and $4 \mathrm{mg} \mathrm{cm}^{-2}$ Pt black cathode both with the alkaline interface). Test conditions: $50^{\circ} \mathrm{C}, 0.1$ A discharge, cathode: $2 \mathrm{dm}^{3} \mathrm{~min}^{-1}$ air $(\mathrm{RH}=100 \%)$, anode: methanol $\left(2 \mathrm{~mol} \mathrm{dm}{ }^{-3}, 2 \mathrm{~cm}^{3} \mathrm{~min}^{-1}\right)$, no back pressures.

electrodes (E-Tek, either $0.5 \mathrm{mg} \mathrm{cm}^{-2} \mathrm{Pt} / \mathrm{C}(20 \% \mathrm{wt}), 4 \mathrm{mg} \mathrm{cm}^{-2} \mathrm{PtRu}_{\mathrm{ox}}$, or 4 $\mathrm{mg} \mathrm{cm} \mathrm{cm}^{-2} \mathrm{Pt}$ black). The polymer-treated electrode was then immersed in $N, N, N$ ', $N$ '-tetramethylhexane-1,6-diamine (Acros Organics, toxic) for 24 $125 \mathrm{~h}$, washed thoroughly with water, soaked in aqueous $\mathrm{KOH}\left(1 \mathrm{~mol} \mathrm{dm}^{-3}\right)$ for $1 \mathrm{~h}$ to convert the polymer interface to the $\mathrm{OH}^{-}$form, and finally washed thoroughly with water to remove any residual $\mathrm{KOH}$. The electrodes were pressed onto the alkaline polymer (freshly converted to the $\mathrm{OH}^{-}$-form) at $100^{\circ} \mathrm{C}$ for $3 \mathrm{~min}$ at $120 \mathrm{~kg}_{\mathrm{f}} \mathrm{cm}^{-2}$.

$130 \div$ The AAEM used in this study had the following relevant properties: $1.14 \pm 0.02 \times 10^{-3} \mathrm{~mol}\left(\mathrm{OH}^{-}\right) \mathrm{g}^{-1}($ dry membrane $) ;\left[\mathrm{OH}^{-}\right]=1.21 \pm 0.05 \mathrm{~mol}$ $\mathrm{dm}^{-3}$, a density of $1.36 \pm 0.04 \mathrm{~g} \mathrm{~cm}^{-3}$, a water content of $15 \pm 2 \mathrm{H}_{2} \mathrm{O}$ molecules / $\mathrm{OH}^{-}$ions, and a thickness of $153 \pm 4 \mu \mathrm{m}$ when fully hydrated; and a thickness of $133 \pm 4 \mu \mathrm{m}$ when fully dehydrated. The conductivity at

$13530^{\circ} \mathrm{C}$ and $\mathrm{RH}=100 \%$ was determined to be $0.0092 \pm 0.0005 \mathrm{~S} \mathrm{~cm}^{-1}$ using standard electrochemical impedance spectroscopic techniques. ${ }^{6}$

$\S$ The $\mathrm{CH}_{2} \mathrm{Cl}$ deformation band at $1680 \mathrm{~cm}^{-1}$ in the Raman spectrum of poly(vinylbenzyl chloride) vanishes, whilst new bands at 1451 and 757 $\mathrm{cm}^{-1}$ appear in the spectrum of the final cross-linked polymer; these bands 140 are reported for $\mathrm{NCH}_{3}$-functionalised quaternary ammonium containing materials $^{6}$ and are also present in the spectrum of poly(vinylbenzyltrimethylammonium chloride). The intense bands at 2765 and $2729 \mathrm{~cm}^{-1}$ present in the spectrum of the diamine are not visible in the spectrum of the final materials, confirming no residual diamine.

145 If Nafion1 15 (DuPont): $0.92 \operatorname{mol}\left(\mathrm{H}^{+}\right) \mathrm{H}^{+} \mathrm{g}^{-1}$ (dry membrane); $153 \mu \mathrm{m}$ thickness and $23 \mathrm{H}_{2} \mathrm{O}$ molecules / $\mathrm{H}^{+}$ion when fully hydrated; conductivity of $0.064 \mathrm{~S} \mathrm{~cm}^{-2}$ at $30^{\circ} \mathrm{C}$ and $\mathrm{RH}=100 \%$.

1 J. R. Varcoe and R. C. T. Slade, Fuel Cells, 2005, 5, 187-200; Y. Wang, L. Li and L. Hu, L. Zhuang, J. Lu and B. Xu, Electrochem. Commun., 2003, 5, 662-666.

2 K. Matsuoka, Y. Iriyama, T. Abe, M. Matsuoka and Z. Ogumi, J. Power Sources, 2005, 150, 27-31; C. Coutanceau, L. Demarconnay, C. Lamy and J.-M. Léger, J. Power Sources, 2006, DOI: 10.1016/j.jpowsour.2005.08.035.

1553 E. Hao and K. Scott, J. Power Sources, 2004, 137, 248-256; L. Li and Y. Wang, J. Membr. Sci., 2005, 262, 1-4.

4 E. Agel, J. Bouet and J. F. Fauvarque, J. Power Sources, 2001, 101, 267-274.

5 E. Gülzow and M. Schultz, J. Power Sources, 2004, 127, 243-251.

1606 T. N. Danks, R. C. T. Slade and J. R. Varcoe, J. Mater. Chem., 2003, 13, 712-721; H. Herman, R. C. T. Slade and J. R. Varcoe, J. Membr. Sci., 2003, 218, 147-163; R. C. T. Slade and J. R. Varcoe, Solid State Ionics, 2005, 176, 585-597.

7 E. N. Komkova, D. F. Stamatialis, H. Strathmann and M. Wessling, J. Membr. Sci., 2004, 244, 25-34.

8 E. H. Yu and K. Scott, J. Appl. Electrochem., 2005, 35, 91-96.

9 E. Chen in Fuel Cell Technology Handbook, ed. G. Hoogers, CRC Press, Boca Raton USA, $1^{\text {st }}$ edn., 2003, ch. 1. 